\section{Organizational culture and relationship marketing: an interorganizational perspective}

\author{
Fabiano Larentis \\ University of Caxias do Sul, Management Graduate Program, Caxias do Sul, Brazil
}

\section{Claudia Simone Antonello}

\section{Luiz Antonio Slongo}

Federal University of Rio Grande do Sul, Management

Graduate Program, Porto Alegre, Brazil

\begin{abstract}
Purpose - This paper aimed to analyze the contribution of interorganizational relationships, specifically between suppliers and clients, to organizational cultural changes.
\end{abstract}

Design/methodology/approach - A qualitative multiple case study in two marketing channels was performed, through in-depth interviews, observation and data analysis based on grounded theory.

Findings - The contribution of trust, commitment, cooperation and learning processes has been identified in the organizational cultural changes and in the reduction of the role conflicts of the boundary spanners. Also, the role of employee turnover to weaken these dimensions and respective relations has been noticed.

Originality/value - The development of an interorganizational culture has been evidenced, as a system of symbols and meanings shared by groups or individuals from different organizations, on a transitional basis, with the predominance of the cultural perspective of fragmentation. It is a culture originated from relationships through intersections of cultures, a culture of boundaries.

Keywords - Organizational culture; relationship marketing; cultural perspectives; interorganizational relationships; interorganizational culture
Received on

01/25/2017

Approved on 06/19/2017

Responsible editor:

Prof. Dr. Ignacio Canales

Evaluation process:

Double Blind Review

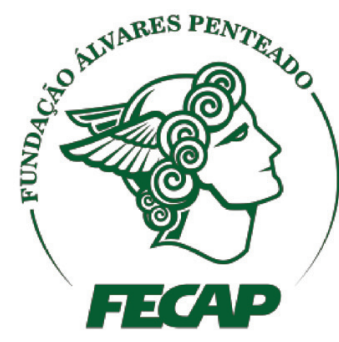

Review of Business Management 


\section{Introduction}

Due to its collaborative nature, Relationship Marketing between companies allows them to reach sustainable competitive advantages and higher business performance, through partnerships and complementary expertise (Gummesson, 2008; Hunt, Arnett, \& Madhavaram, 2006). Nonetheless, based on the importance and practices of relationship marketing, it is important to consider the business processes associated with it.

Relationships are complex and multifaceted because they demand not only resources and partners' selection, but also the formation of trust and commitment by frequent and qualified interactions, as well as the level of cooperation and the existence or emergence of compatible values (Hunt, Arnett, \& Madhavaram, 2006; Morgan \& Hunt, 1994; Palmatier, Dant, Grewal, \& Evans, 2006). Regarding that, what happens among individuals, from different organizations, involved in these relationships? What is the role of organizational culture?

These questions are asked because the practices of relationship marketing come from the organizational area of marketing, a boundary area in companies, where individuals from different organizations interact with each other: the so-called boundary spanners (people from organizational boundaries). Boundary is a line or region which divides and set limits (Halley, 2001). Organizational culture, on the other hand, is a system of common meanings and symbols, shared in the organizational context (Alvesson, 2013). Meanings lead to the interpretation of the object/speech, and symbols to the expressions of these meanings.

The frequency and the quality of these interactions, along with the emergence mainly of trust, commitment and cooperation, can make individuals from different organizations start understanding each other in different ways, thus being able to share symbols and meanings, and the organizational culture (Alvesson, 2013). Also, organizational culture from an interorganizational perspective is noticeable: groups do not limit themselves to one organization's domain (Van Maanen \& Barley, 1985). Hence, organizational cultures involved can, through particular systems of meanings and symbols, be changed because of interorganizational relationships, due to relationship marketing strategies and processes.

In that context, comprehending organizational culture is comprehending organizational life in all its richness and variation (Alvesson, 2013). Organizational culture can be specific to determined groups and contexts, not only a consistent set of symbols and meanings shared by all organizational members (Martin, Frost, \& O'Neil, 2006).

Therefore, this study aims to analyze the contribution of interorganizational relationships to organizational cultural changes, through a multiple case study in two Brazilian companies. In particular, it is intended to comprehend how aspects of the relationship interfere in the system of symbols and meanings, and identify the existence of an interorganizational culture, arising from interactions.

This study is justified firstly because it connects two subject areas traditionally investigated separately. The role of organizational culture in relationship marketing is significantly under-researched, despite consensus about the importance of this topic (Iglesias, Sauquet, \& Montaña, 2011) Secondly, it considers the development of interorganizational relationships through cultural lenses, bearing in mind relationship marketing practices, which means the formation and presence mainly of trust and commitment (Gummesson, 2017), thus contributing to academics as well as to managers. Current studies on organizational culture interface, on an interorganizational context, normally focus more on organizational culture differences rather than on organizational culture compatibilities (Lu, Plewa, \& Ho, 2016). In addition, research should consider how the firm's culture is developed from the enactment of 
marketing activities over time, and how divergent structures and cultures are aligned (Moorman \& Day, 2016). Thirdly, an emerging market context is investigated. According to Narasimhan, Srinivasan and Sudhir (2015), research on emerging markets is increasingly critical to academics and managers, by providing managerial guidance and expanding the substantive and theoretical knowledge of markets and marketing.

\section{Theoretical background}

\section{I Organizational culture}

Culture implies a collectivity. Organizations are symbolic entities, because they work by following models implicit on their members' minds (Hofstede, 2001), which will interfere in the satisfaction of the ones involved and, consequently, in the company's performance (Gregory, Harris, Armenakis, \& Shook, 2009). Culture is a historical product from a group, it affects interpretations and it guides behaviors (Alvesson, 2013; Hogan \& Coote, 2014; Van Maanen \& Barley, 1985; Vetráková \& Smerek, 2016; Yin, Lu, Yang, \& Jing, 2014).

Cavedon (2003) deals with organizational culture as a network of meanings flowing inside and outside the organizational space, being simultaneously ambiguous, contradictory, complementary, diverse and analogous, showing the organizational homogeneity and heterogeneity. For Alvesson (2013), organizational culture is seen as a system of symbols and meanings, shared in the organizational context, in a way through which individuals define their environment, express their beliefs and make judgments. Meaning refers to the way an object or expression/speech is understood. Symbol condenses a set of meanings in a specific object and announces it in a compact way. The author stresses that culture does not necessarily establish clearness and consensus among large groups of people, but it guides them to deal with the instances of ambiguity without much anarchy.

Therefore, organizational culture involves symbols and meanings, by considering symbols the expression of meanings, such as in language, history, myths, rituals, ceremonies and artifacts (Alvesson \& Sveningsson, 2008). Symbols are external sources of information and are used as representation of social and psychological processes. Rites, rituals and ceremonies are acts that shape expressions and give value to symbols. Myth, as a dramatic narrative of imagined events, usually explains origins or changes, combine the cultural shapes and consolidate them in a specific event (Strati, 1998).

Organizations are marked by social practices that can be considered cultural. These practices, however, may not represent the organization as a whole: culture is developed within work environments (Van Maanen \& Barley, 1985). In this sense, Martin et al. (2006) propose four different perspectives of organizational culture: perspective of integration, perspective of differentiation, perspective of fragmentation and a three-perspective framework. In the perspective of integration, culture is a set of cultural expressions, which generate the consensus of all the organization, called unitary culture by Van Maane and Barley (1985). According to them, this happens when the members of an organization deal with the same problems and when a common system of understanding is adopted

It is questionable, however, if organizational culture is typically a characteristic of the organization as a whole, or if it is particularly of groups or subcultures inside of it (Deshpandé \& Webster, 1989). Organizations are marked by social practices which can be considered cultural, but these practices may be confined to specific groups, or subcultures (Van Maane \& Barley, 1985), in other words, the perspective of differentiation. An organization can include culturally diverse departments and work groups (Hofstede, 2001).

In the perspective of fragmentation, the relationships among the cultural expressions are neither clearly consistent nor clearly inconsistent. They are complex and have many contradictory 
and troublemaking elements. Consensus would not encompass the entire organization, neither would it be specific to certain organizational subgroup. It would be transitory and specific to a determined issue, leading to short term affinities among individuals and being replaced by different models, as other questions draw attention. An organizational culture is not a solid and wellshaped whole or a stable set of subcultures, which is easy to comprehend. However, it refers to mixtures of cultural manifestations from different kinds and levels (Alvesson, 2013).

Finally, Martin et al. (2006) present a three-perspective framework, in which some values, interpretations and practices generate consensus in all the organization, others cause conflict and some have not been well defined yet. In organizations, according to them, there would be a simultaneous existence of elements of integration, conflict, power and uncertainty.

On the other hand, the development of a culture is a learning process, since the organization's founders (Dauber, Fink, \& Yolles, 2012; Gagliardi, 1986) consider a set of beliefs, even in an unclear way. As certain groups learn how to deal with their problems of adaptation and integration, organizational culture develops, which is taught to new members provided it is considered and felt to be correct (Schein, 1991). Responses to an organization by its members are formulated to solve a problem and also to decrease the anxiety related to it (Gagliardi, 1986). Nonetheless, more powerful individuals and groups can influence others' interpretation about events (Lucas \& Kline, 2008).

Changes in culture, besides material aspects, also include a redefinition of meanings, but not necessarily of values and key-meanings (Alvesson, 2013; Alvesson \& Sveningsson, 2008). On the other hand, some aspects which are more rooted in culture are difficult to change, as well as the culture may change to remain what it has always been: changes in behavior do not necessarily mean changes in beliefs and values (Alvesson \& Sveningsson, 2008; Gagliardi, 1986;
Ogbonna \& Harris, 2014). However, culture is constantly created and transformed as groups of people socially interact with each other, in a state of flux without any clear boundary (Lee, Kim, \& Park, 2015). In this sense, the openness to new ideas is essential to cultural change (Alvesson \& Sveningsson, 2008).

\subsection{Relationship marketing and interorganizational relationships}

Organizations which are part of a value chain recognize the benefits of relationship marketing, defined as a process of interaction and engagement which establishes, develops and maintains long-term cooperative relationships with mutual benefits among the parties (Hakansson \& Snehota, 1995; Morgan \& Hunt, 1994; Palmatier, 2008). Interaction shows that the results come from actions and reactions, performed by those involved, because both sides play active roles (Hakansson \& Snehota, 1995; Pels, Moller, \& Saren, 2009).

According to Cannon and Perreault (1999), effective relationships help the involved parts to manage uncertainty and dependency, increase the efficiency through cost reductions and improve market orientation, through a better understanding of customers. Relationship marketing aims to generate long-term profitable relationships between partners (Miquel-Romero, Caplliure-Giner, \& Adame-Sánchez, 2014). In this regard, the more both parties are motivated to maintain the relationship and are imbricated with each other, the lower the risk of relationship dissolution and the more willing they are to invest in that relationship - particularly in nonrecoverable investments (Scheer, Miao, \& Palmatier, 2015).

Nevertheless, relationship marketing strategies are not a solution for all clients in all possible situations (Agariya \& Singh, 2011; Schakett, Flaschner, Gao, \& El-Ansary, 2011). Relationships depend on time in order to be developed. Moreover, some clients do not wish to maintain a close relationship with their suppliers 
and vice versa. In this sense, relationships need to be stable enough to last for a while and dynamic enough to ensure the development of capabilities (Batt \& Purchase, 2004).

Trust, commitment and cooperation are some of the relationships key-elements (Agariya \& Singh, 2011; Gummesson, 2017; Palmatier et al., 2006). Trust, a company's belief on the honesty and goodwill of the other (Geyskens, Steenkamp, \& Kumar, 1999), makes partners more likely to share information, increases the feeling of safety and reduces opportunism (Palmatier et al., 2006). However, it decreases in unstable environments (Kang \& Jindal, 2015). Commitment is the permanent will to keep a relationship (Palmatier et al., 2006). Moreover, relationships are shaped by a social environment which allows cooperation, when past interactions are seen favorably and future actions are believed to be constructive (Morgan, 2000). Commitment influences cooperation in a positive way; both are positively influenced by trust (Morgan $\&$ Hunt, 1994; Palmatier et al., 2006).

In respect with this aspect, Plewa (2009) states that, in uncertain situations, people must pay attention to the increase in trust and to the decrease in the differences among the partners; in more stable conditions, one must focus on developing commitment. MiquelRomero et al. (2014) argue that the generation of trust and commitment, which ultimately results in loyalty, is a strategic goal and a source of long-term profitability, albeit greater interdependence proportion is associated with greater dyadic cooperation, which is likely to be significantly lower when interdependence is based on switching costs other than relationship value interdependence (Scheer et al., 2015).

In relationships, a significant agent is the boundary spanner, who acts like an organization representative or interpreter of the external environment across organizational boundaries (Araujo, Dubois, \& Gadde, 2003), e.g. sellers, buyers and managers related to interorganizational relationships. Boundaries are places of highly charged contact, where differences meet and exchanges happen (conflict, power and resource conversion) (Halley, 2001). Boundaries help to stablish and keep habits, expectations and roles, and they also provide defense and allow exchanges (Araujo et al., 2003, Halley, 2001). The more the organizations rely on interorganizational relationships, the more their boundaries may change (Araujo et al., 2003). Hence, interorganizational relationships can be seen like pipelines across organizational boundaries (Ballantyne, Christopher, \& Payne, 2003).

Boundary spanners represent the most crucial vehicle for building and maintaining strong relationships (Palmatier, 2008). Nonetheless, one of the problems which is very much related to them is the role conflict, defined as the faced prominent uncertainties (Singh \& Rhoads, 1991). As they interact with members of other groups, they may experience conflicting expectations about how to perform their role, which may lead to negative effects in their relationships (Friedman \& Podolny, 1992). The existence of good quality personal relationships reduces the role conflict, attenuating divergent meanings (Haytko, 2004).

\subsection{Organizational culture and relationship marketing}

Not only does the relationships development demand investment of resources and selection of partners, but also trust, compatible values, commitment, stability, frequency and quality of interactions (Gummesson, 2008; Iglesias et al., 2011; Palmatier et al., 2006). It depends on how trust and commitment are transformed into cooperation and, therefore, into action. On the other hand, as stated by Luthans (2010), the more activities are shared, the more interactions will take place and the stronger the feelings among the people will be; the more frequent the interactions are, the more the activities and feelings will be shared; the stronger the feelings are, the more people will share activities and interact. 
Relationships are cultural: interactions are built in cultural premises (Ellis, Lowe, \& Purchase, 2006). Benefits of the relationships will depend on how much they are valued at the organizational level and rooted into organizational culture (Winklhofer, Pressey, \& Tzokas, 2006). Relationships involve the meeting point of different cultures (Plewa, 2009). Concerning this, it is from the compatibility of values, which precedes trust and commitment (Morgan, 2000; Morgan \& Hunt, 1994), that one can identify similarities among organizations (past experiences, current actions and future expectations).

Ambiguity and complexity are reasons for cooperation to take place, because interdependent organizations with similar interests, even though they have different views, generate a degree of familiarity and solutions together (Pitsis, Kornberger, \& Clegg, 2004). Based on compatible values, trust, commitment, cooperation and ways to perceive and deal with reality, it is possible to notice that relationships may interfere in the involved organizational cultures, considering the cultural perspectives from Martin et al. (2006).

However, can these cultural changes lead to the development of a culture which involves people from different organizations, an interorganizational culture? Interorganizational culture may be perceived as a network of meanings and symbols which flow among organizational boundaries, an interaction and combination among symbols and meaning that may lead to new meanings. Saenz, Revilla and Knoppen (2014) define interorganizational culture as a set of norms or values shared by different organizations.

In addition, the higher the frequency and level of communication in the relationships, the higher the chance of culture integration; the more cultural understanding among the partners, the more relationship quality (Iglesias et al., 2011; Palmatier, 2008). However, cultural differences are higher in relationships with worse performance (Beugelsdijk, Koen, \& Noorderhaven, 2009) and choosing a partner with similar values is likely to sustain long-term cooperation (Wang \& Zhang, 2017).

Hence, it may be noted that interorganizational culture is not necessarily the only culture for partner organizations (perspective of integration). In this regard, the perspective of differentiation, perspective of fragmentation or the three-perspective framework might be considered (Martin et al., 2006).

\section{Method}

This research is classified as a qualitative multiple-case study (Merriam, 2009; Yin, 2014). Two strategic business units (SBUs) located in the south of Brazil, from different industrial groups, participated. One of them manufactures customized furniture (Company $\mathrm{M}$, founded in mid 1990s). The other provides financial services (Company S, founded in mid 1980s). These SBUs have been chosen because of the close relationship with their sales intermediaries (large number of interactions and the presence of trust, commitment and cooperation).

As for the unit of analysis, the dyad has been considered (Achrol, Reve, \& Stern, 1983) with the participation of individuals from supplier companies and sales intermediaries involved in the relationships. Regarding the dyads, Company $\mathrm{M}$ only has exclusive furniture stores as intermediaries, with an exclusive contract by region. Company $S$ works with a franchising system. Managers, supervisors, analysts and assistants (from suppliers) and owners (from intermediaries) participated in the research. Intermediaries have been chosen by the criterion of high level of interaction with the companies (both positive and negative relationships).

Data was collected in four different stages. In Stage 1, during five months, fifteen in-depth personal interviews were conducted in Company $\mathrm{M}$ : one with the sales manager, the marketing manager and a former sales manager, respectively; six with sales supervisors, four with sales assistants and one with the administrative supervisor and the store design supervisor, respectively. Five 
were conducted in furniture stores (owners). A same semi-structured script based on specific objectives and on the theoretical background was used, whose questions were related to quality of interactions, trust, commitment, learning, cooperation, role of boundary spanners, cultural meanings, representative facts about the organization's evolution, cultural similarities and differences inside the company and across groups and organizations, and cultural changes according to relationship development. Moreover, one observation of a Furniture Stores Convention was performed. In Stage 2, during three months, nine in-depth interviews were conducted in Company S (one with the franchise manager, the customer service supervisor, the finance analyst, the customer service assistant and the marketing assistant, respectively; two with administrative assistants and sales assistants, respectively) and two with franchisees (owners), with the same script used for Company M. In this case, the observation was not authorized by Company S.

Having the results from the first and second stages and their relations to the theoretical background, a second semi-structured script was developed, whose questions were related to interorganizational interactions, conflicts and uncertainties in relationships, cultural manifestations and their relations with relationships, personnel turnover, cultural changes through relationships and expectancies with relationships. In Stage 3, during one month, six interviews were conducted in Company M: one with the sales manager, the marketing manager and the administrative supervisor, respectively; two with sales supervisors; one with a store owner. In Stage 4, during one month, there were nine interviews in Company $S$ : one with the franchise manager, the customer service supervisor, the finance analyst, the customer service assistant, the marketing assistant, an administrative assistant and a sales assistant, respectively; two with franchisees (owners). The interviews, which lasted about 65 minutes (Stages 1 and 2) and 40 minutes (Stages 3 and 4), were recorded and transcribed.
The number of interviews in each stage was based on the redundancy criterion (Merriam, 2009).

Considering quality in the process of qualitative research (Gubba \& Lincoln, 2011; Miles, Huberman, \& Saldaña, 2014; Yin, 2014), there was reliability due to the coherence in data collection (time devoted to data collection procedures, choice of respondents and kind of interaction with the interviewees). About its validity, the data triangulation was carried out through the interviews with the people from the dyads, in four different stages, along with the use of two collecting techniques, which provided enough evidence to the understanding of the phenomenon, contributing with the plausibility and credibility of the results.

The data analysis procedure derived from the grounded theory was used (Charmaz, 2014). Based on the procedures of Charmaz (2014), from guiding dimensions (trust, commitment, cooperation, learning, difficulties in relationship, meanings and symbols), derived from the clustering of questions from the interview and observation scripts, excerpts of data were summarized, generating the main ideas (codes). Lastly, a microanalysis was conducted, when the codes, clustered, generated categories.

\section{Results and discussion}

\section{I The interorganizational relationships in companies: general aspects}

The activity with exclusive stores in Company $\mathrm{M}$ and with franchises in Company $S$ demands more closeness to the channel intermediaries. Even though there are contractual agreements, they do not seem to limit social and cultural processes linked to the relationship. The sales processes involved may be considered complex. Company $M$ deals with projects and assemblies, which mobilize the final consumers' lives and their emotions. They also deal with other professionals, such as architects and interior designers. Company $S$ deals with several financial rules, which influence sales argument development. 
According to the interviewees, in general, the importance of the relationship should be evident through the level of concern in doing what has been promised, through the constant information exchange, and through the integration among the teams, reliability on what is being made, through the willingness to learn and to solve problems, emphasizing the presence of the central elements of relationship marketing: trust, commitment and cooperation (Gummesson, 2017; Palmatier et al., 2006), in addition to the importance of learning, mainly informal, which strengthens the development and performance of relationships (Altinay \& Brookes, 2012; Ellis et al., 2006). Some interview excerpts are presented:

Trust: As he [franchisee] understood our philosophy and accepted it [contribution to integrate more]. He lowered his guard. I understand that there is a process and that he can contribute to this process, which is not always the way he wants it, but that we can reach a common ground. That compared to the last eight years you can see clearly. They understand more. The process has changed (Marketing Assistant S).

Commitment: They have greatly increased the number of employees to give us support. They provide very interesting trainings. They are not letting us adrift, they are present. Of course the result is what we are going to do. This presence of theirs seeking alternatives demonstrates that they are committed (Franchise S).

Cooperation: They (store) start looking for new markets, know that the company will give them support. Before they were very afraid, because of their investment. Now there are many possibilities with this store, they ask for opinions, suggestions. There is this opening, of throbbing. He gave them back. I heard from this store at the beginning that they were orphaned and abandoned (Sales Supervisor M).
Learning: We have learned a lot [from the franchises]. They have sensitivity on their fingertips. Many practices that worked well in one franchise we spread to others. It is a great learning when we visit them. Learning what not to do and what to do. They are very critical in raising the "whys", but there are times when they realize that certain issues will contribute to the safety of $S$ and consequently to the safety of the franchise and they buy that idea. There is a spirit of collaboration (Sales Assistant S).

Table 1 shows a comparative summary between $M$ and $S$, based on the empirical findings. Broader aspects, like the way trust is seen, the importance of cooperation, learning processes and problems are similar among them. The quality of trust, cooperation actions and learning are better at Company S.

Moreover, the main relationship difficulties identified were related to employee turnover level, mainly the intermediaries' sales teams, and to the understanding of the other side. High turnover levels impact negatively in the development of the organizations (Mohr, Young, \& Burgess, 2012). Turnover, associated to reduced available time for visiting points of sale by the supplier companies, leads the relationship to happen mainly between owners or managers of the intermediaries. In the suppliers, mainly in staff departments, the difficulty to understand the other side predominates, due to the lack of knowledge of the intermediaries' reality.

Whenever you have a franchise with higher employee turnover, the processes also come with a higher difficulty level. Usually, when the franchise has less turnover the sales area plays the expected role, the operational / administrative staff already realizes what is missing or what needs to be arranged. Turnover is a big problem. What causes customer dissatisfaction is turnover (Financial Assistant S). 
Some of these difficulties would be greater if companies were not open to listen to the intermediaries' problems. Such findings indicate a relation between organizational cultures and relationship practices (Ellis et al., 2006; Gummesson, 2008; Iglesias et al., 2011; Winklhofer et al., 2006).

Table 1

\section{Comparisons regarding to relationship - Companies $M$ and $S$}

\begin{tabular}{|c|c|c|c|}
\hline \multirow{6}{*}{ Simila rities } & Dimensions & Company $\mathbf{M}$ & Company S \\
\hline & Trust & \multicolumn{2}{|c|}{$\begin{array}{l}\text { - Importance of transparency } \\
\text { - Reliability about information provided, actions performed and people } \\
\text { - Sharing of information and ideas }\end{array}$} \\
\hline & Commitment & \multicolumn{2}{|c|}{$\begin{array}{l}\text { - Complying with responsibilities } \\
\text { - Reaching objectives } \\
\text { - Taking good care of the people and the business }\end{array}$} \\
\hline & Cooperation & \multicolumn{2}{|c|}{$\begin{array}{l}\text { - Discussion of problems, willingness to listen and help } \\
\text { - Partial perception regarding the reality of the intermediaries }\end{array}$} \\
\hline & Learning & \multicolumn{2}{|c|}{$\begin{array}{l}\text { - Company learning from the intermediaries mainly about the market } \\
\text { - Intermediaries learning from the companies mainly about management practices } \\
\text { - Learning cultural elements (meanings) } \\
\text { - Preponderance of informal learning processes }\end{array}$} \\
\hline & $\begin{array}{l}\text { Difficulties in the } \\
\text { relationship }\end{array}$ & \multicolumn{2}{|c|}{$\begin{array}{l}\text { - Difficulty in understanding the other side } \\
\text { - Role conflict of the boundary spanners } \\
\text { - Employee turnover }\end{array}$} \\
\hline \multirow{3}{*}{ Peculia rities } & Trust & $\begin{array}{l}\text { - Lack of clear rules } \\
\text { - Lack of greater autonomy }\end{array}$ & - More transparency \\
\hline & Cooperation & $\begin{array}{l}\text { - Relationship with several } \\
\text { professionals }\end{array}$ & - Better quality of contacts \\
\hline & Learning & $\begin{array}{l}\text { - Need for external support to learn } \\
\text { from past practices } \\
\text { - Prevalence of learning by doing }\end{array}$ & $\begin{array}{l}\text { - More exchange of information } \\
\text { - More learning from exchanging experiences } \\
\text { - More intense trainings }\end{array}$ \\
\hline
\end{tabular}

\subsection{Companies' organizational cultures}

A high number of similar meanings has been noticed, mainly about positive aspects such as ethics, respect to people, stability and relationship. Concerning differences, Company
$M$ presented less daring and lower agility, mainly due to the centralization of decision-making. In Table 2, we present the summarized empirical findings. 
Table 2

Organizational cultures in the researched companies

\begin{tabular}{|c|c|c|}
\hline Comparisons & Company M & Company $S$ \\
\hline Similarities & $\begin{array}{l}\text { - Actions taken gradually } \\
\text { - Balance between reason and emotion } \\
\text { - Ethics } \\
\text { - Flexibility }\end{array}$ & $\begin{array}{l}\text { - Humbleness } \\
\text { - Importance of the relationship } \\
\text { - Trust as a value } \\
\text { - Stability }\end{array}$ \\
\hline Differences & $\begin{array}{l}\text { - Greater focus on product and production } \\
\text { - Less agility and daring } \\
\text { - Less formality } \\
\text { - Self-sufficiency }\end{array}$ & $\begin{array}{l}\text { - Freedom to create } \\
\text { - Greater focus on learning } \\
\text { - Greater focus on client and on results } \\
\text { - More autonomy to make decisions }\end{array}$ \\
\hline $\begin{array}{l}\text { Differences with the } \\
\text { industrial group of } \\
\text { origin }\end{array}$ & $\begin{array}{l}\text { - Greater openness to innovation } \\
\text { - Less traditional } \\
\text { - More dynamism } \\
\text { - More importance to relationship } \\
\text { - More interest in challenge }\end{array}$ & $\begin{array}{l}\text { - More freedom to create } \\
\text { - Less traditional } \\
\text { - More dynamism } \\
\text { - More importance to relationship } \\
\text { - More autonomy to make decisions }\end{array}$ \\
\hline
\end{tabular}

Both companies have differences related to the other units of the industrial groups of which they are part. Because of their goods/services, their intermediaries, the markets in which they are present and their previous leaders, companies $\mathrm{M}$ and $\mathrm{S}$ show more dynamism, more importance given to the relationships and are less traditional. In Company $M$, there is openness to discuss ideas and submit projects, but very consistent arguments are necessary to get an approval by the board of directors. In Company $S$, the greater decentralization leads to a larger number of decisions to be made at the intermediate hierarchical levels. Another aspect is the focus on client, on teamwork and on the concern about problem-solving.

We perceive clearly very industrial characteristics, where they came from (founders). But there is a greater humanization here, a humility with professionalism. I worked for a company where there was rudeness in the deal. Here the way you are treated is polite, not formal. There is respect for the human being (Sales Manager $M$ ).

Furthermore, in both companies, it was possible to identify the difficulties to replace intermediaries who present unsatisfactory sales and financial performances. One of the reasons is the way the replacement is seen, when it is preferable to give a chance to intermediaries to improve, related to the meanings associated to stability.

Comparing companies with intermediaries, culturally, many similarities have been found. Some of the companies' characteristics were previously appreciated by the intermediaries, such as ethics, simplicity, stability and importance given to relationships. The intermediaries who have a closer relationship are the ones who perform these characteristics the most. One possible reason for that relates to the intermediaries that have already been company's employees, and to the intermediaries with compatible values since the beginning of the relationships. Differences have been observed mostly because of the nature of business. The intermediaries deal with retailing and have a more oriented view of the market, while the companies, mainly Company $M$, have a more industrial view.

They [company and board] are very humble; do not show off what they have. I also came from a humble situation. There is no effort on the part of everyone in the company to 
behave in certain ways, it is not artificial, it is natural. Everyone is available to help. They are polite, humble people (Intermediary $M$ )

As for the cultural expressions (symbols), the myths of the industrial groups founders have been identified, people of humble origin. There is also the myth of the "Ugly Duckling", allusion to the profitability of Company $\mathrm{M}$ and the need for investments. From the ceremonies, which involve several rites, besides the internal confraternization parties, there are also fraternization events with the intermediaries. In Company $M$, there is the "Furniture Stores Convention", when actions are made official and ideas are shared. In Company $S$, there is a Franchisee Meeting, at least once a year, under the franchisee's responsibility, for the exchange of ideas and integration with new intermediaries. Another aspect that stands out is the constant awards that the company receives, which usually enhance the team spirit.

\subsection{Organizational cultural changes}

Cultural changes in expressions as well as in meanings, which happened over time, could be identified, both for intermediaries and for companies, with a contribution of the interorganizational relationships, regarding that a culture develops as certain organizational groups learn how to deal with problems as well as the right way to perceive them across time (Schein, 1991). Summarized empirical findings are presented in Table 3.

Table 3

\section{Organizational cultural changes}

\begin{tabular}{ll}
\hline $\begin{array}{l}\text { Contribution from companies to } \\
\text { intermediaries in cultural changes }\end{array}$ & - Compatible values \\
\hline $\begin{array}{l}\text { Contribution from intermediaries to } \\
\text { companies in cultural changes }\end{array}$ & - Intermediaries (owners) as employees of the companies in the past \\
\hline Contribution of others & - Past experiences with other suppliers \\
\hline & - Cultural aspects beyond the involved organizations (like professional subcultures) \\
Relationships between supplier and & - Cultural characteristics facilitating the rise or strengthening of others \\
intermediate contributions & - Role of leadership \\
& - Asymmetry of power \\
& - Conservative and stable nature of the cultures \\
\hline
\end{tabular}

Considering the contribution from companies to intermediaries in cultural changes, compatible values, specifically meanings/ values appreciated by intermediaries, have been identified. Interviewees emphasized humbleness and the importance given to relationships, which were reinforced with the interaction.

Cultural changes are also related to management practices, because of intermediaries' lack of management references. In Company $M$, the "Concept", set of strategic and operational guidelines, is part of the vocabulary and the store owners' practices. In Company $S$, there is a strong influence of people management practices. There is also the situation of former employees of the companies who are now intermediaries. In this case, characteristics of the organizational culture of the supplier, for being, in the past, the main reference of organization to them, have contributed to the development of the organizational culture of the new company, although the challenges faced to play the role of entrepreneurs.

Our school is there. In our values there is a lot of S. I believe that a franchise with people that were created within the $S$, makes the values much more present. But, over time, values are absorbed by osmosis. I see the franchise network very transparent. We are 
not only thinking about ourselves, but about the network. By strengthening the network, we are strengthening ourselves (Franchise $S$ ).

A contribution from intermediaries to companies relates to a better comprehension of market needs. In Company $S$, there was a change in its employee's perception about franchises market in trainings delivered by them to the franchises' personnel. Shared market experiences provide shared understanding (Gebhardt, Carpenter, \& Sherry, 2006).

I think the market view by Company $S$ has evolved a lot. Today we can change some things inside there. They are listening more. The market determines the paths. After we have talked a lot, they begin to understand what the market wants (Franchise S).

Another point is the intermediaries' past experiences with other suppliers, contributing to the current ones. In Company $\mathrm{M}$, one of the entrepreneurs with the best performance on the store network, was an exclusive retailer of another brand for many years, with a very intensive focus on results. This store owner, despite disapproving such an aspect, keeps having a greater focus on results than Company $M$, heritage of the former supplier.

Some retailers brought interesting elements to the network, which was something they were seeking to incorporate as a value, the search for profit by sale, the will to sell, which it was not and perhaps not yet an $M$ value. They brought values but also incorporated themselves into the $M$ philosophy (Former Sales Manager $M$ ).

Moreover, there was a contribution of others' meanings, external to suppliers and intermediaries, which shows a relation to professional subcultures (Martin et al., 2006; Van Maanen \& Barley, 1985). In Company M, architects are considered opinion makers in the market. Some of their aspects, such as vocabulary and worldview, have been incorporated to the store owners. Similar role is attributed to the franchising consultants, in Company S.

\begin{abstract}
These other [top performers] retailers already have seen the whole, the concept of the product, the design, an understanding because they have a stronger dialogue with the architects, they know the architect's language (Designer $M$ ).
\end{abstract}

On the other hand, a cultural characteristic may allow or facilitate the rise or strengthening of another cultural characteristic. Culture is transformed as people socially interact with each other (Lee et al., 2015), and openness to new ideas is essential to cultural change (Alvesson \& Sveningsson, 2008). The companies' openness level to new ideas enabled a better approach to the market. Moreover, a greater interaction of the companies with the intermediaries and the need to solve problems, mainly in Company $S$, ended up making departments that do not have direct contact with the market change their point of view. The perceptions from the operational department became more similar with the ones from the sales department, leading to the approximation of company's organizational areas.

Leaders shape the culture (Moorman \& Day, 2016). The role of leadership in cultural changes was identified in Company $M$, with the former sales manager who developed the "Concept". In Company S, with a former director, who launched many strategies of people management. Also, some evidence related to asymmetry of power has been identified, bearing in mind the influence of more powerful individuals and groups on other's interpretation about events (Lucas \& Kline, 2008).

With regard to this, considering the conservative and stable nature of the cultures (Alvesson \& Sveningsson, 2008; Gagliardi, 1986), many of the meanings remain together within the companies and intermediaries. One example 
is the "Concept", previously mentioned. The manager responsible for its elaboration had left and, after that, it has not been widely used, but even so, it remained with the store owners. People leave, but culture remains. In Company $S$, the people management practices were influenced by a former director.

Another manager [after the former one who developed the "Concept"] tried to eliminate the Concept, but they realized that they would never be able to do it, because it is impregnated. The retailers asked for this Concept to return. $M$ may change all the retailers, but the former manager's face remains, the Concept remains (Retailer $M$ ).

Cultural changes, found in some people, groups or symbols and meanings, need the relationships to become stronger and to be spread (Luthans, 2010). Thus, based on Ellis et al. (2006) and Alvesson and Sveningsson (2008), the cultural changes identified probably took place mainly due to interaction and cooperation moments, learning processes, trust formation and commitment. However, these changes depended on a cultural background that had already been present in both companies.

\subsection{Developmentofan interorganizational culture}

According to the findings, relationship marketing in a interorganizational context, mainly through trust, commitment and learning, contribute to cooperative behavior and to the changes in some aspects of the involved organizational cultures. These changes, in turn, depend on the role conflict and boundary spanners turnover. According to Lu et al. (2016), maintaining a successful relationship lies in assuring that organizational cultures between partners are compatible.

Therefore, one can state the existence of an interorganizational culture, in a specific and restrict way, which depends mainly on the interorganizational relationships, with predominance of the cultural perspective of fragmentation (Martin et al., 2006), identified in the sharing of some meanings among individuals of different organizations, as the sales and staff departments with the intermediaries, and the board of directors with the intermediaries. These relations are represented in the proposed conceptual framework (Figure 1), in which the three-perspective framework may be identified (Martin et al., 2006) in the development of an interorganizational culture. There are the Supplier's Culture (a) and Intermediary's Culture (b), from a perspective of integration, symbols and meanings shared all over a company (Martin et al., 2006; Van Maanen \& Barley, 1985), and the Supplier's Departments Culture (c) and Intermediary's Departments Culture (d), from the perspective of differentiation, in which specific meanings are confined to specific working groups (Martin et al., 2006; Hofstede, 2001; Van Maanen \& Barley, 1985). 


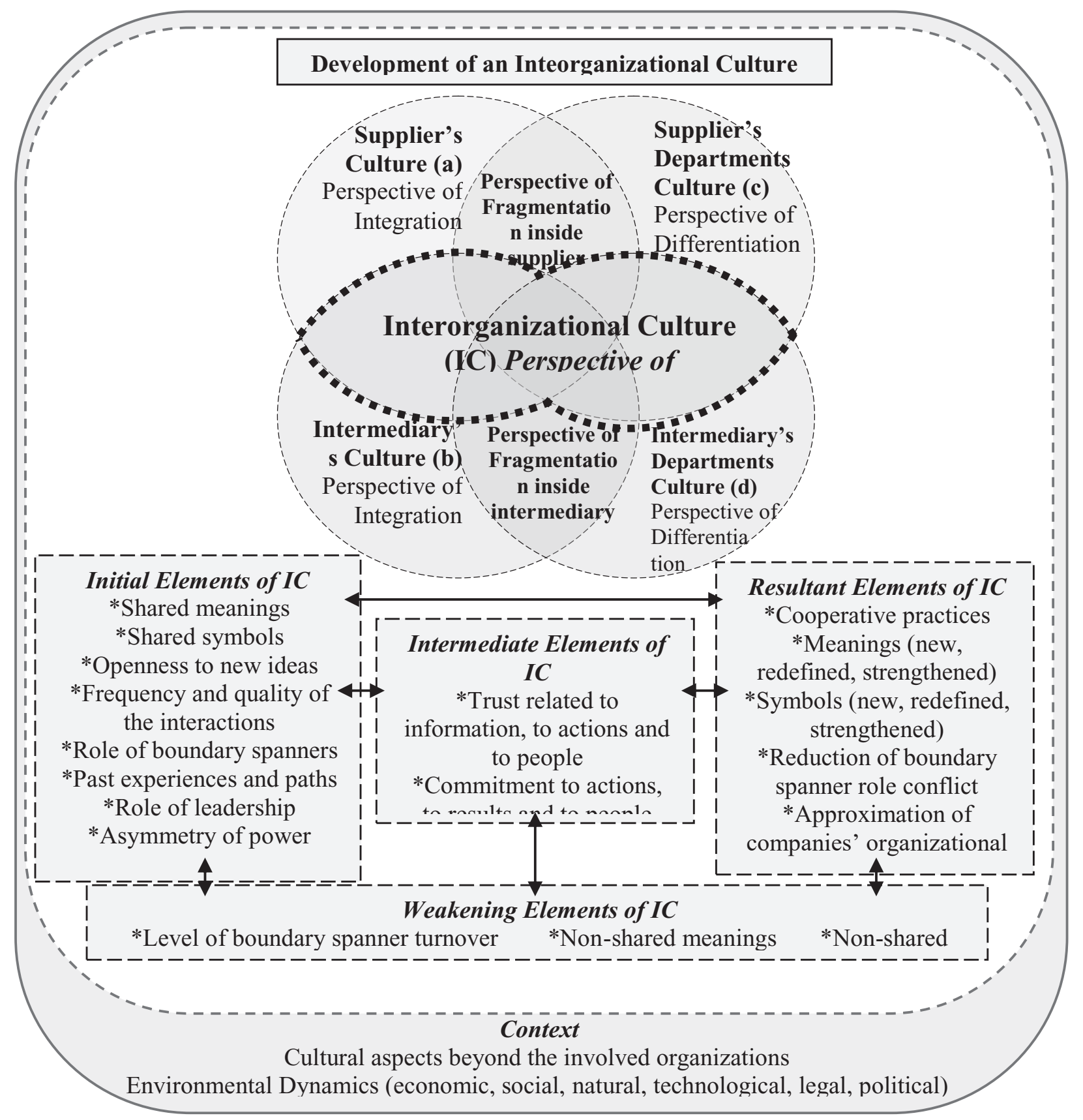

Figure 1. Conceptual framework: Development of an interorganizational culture

It is assumed that the interorganizational culture would develop in the intersection areas between the supplier's cultural perspectives ("a" and "c") and the intermediary's cultural perspectives ("b" and "d"), from the perspective of fragmentation, in which consensus would be specific to a determined issue or context (Martin et al., 2006). The perspectives of fragmentation inside the supplier and intermediary would play an indirect role in its development. These intersection areas reinforce the nature of interorganizational culture as a network of meanings flowing inside and outside the organizational space, constantly created and transformed as groups of people socially interact with each other, in a state of flux without any clear boundary (Cavedon, 2003; Lee et al., 2015). 
The conceptual framework proposes that the development of an interorganizational culture, based on initial elements (shared meanings and symbols, openness to new ideas, frequency and quality of interactions, role of boundary spanners, past experiences and paths, role of leadership and asymmetry of power), is influenced by the interorganizational relationships, through intermediate elements (trust related to information, to actions and to people, commitment to actions, to results and to people, learning processes and results), which will be able to contribute later with the resultant elements (cooperative practices, new, redefined and strengthened meanings and symbols, reduction of boundary spanner role conflict and approximation of companies' organizational areas). These elements, and relations among them, are influenced by the weakening elements (level of boundary spanner turnover and nonshared meanings and symbols). Furthermore, this development is related to the context, beyond the involved organizations (cultural aspects, like other organizational cultures and elements of national cultures, as well as environmental dynamics). It is important to note that the initial, intermediate, resultant and weakening elements, as well as the context, were originated from emergent categories identified in the study, grounded on the findings.

From a cultural approach, boundaries are defined based on shared meanings, and culture is transformed in a state of flux without any clear boundary: organizational cultures form mix of cultural manifestations (Alvesson, 2013; Lee et al., 2015). Hence, in the proposed framework dashed lines represent the permeability among cultural perspectives, elements related to the development of an interorganizational culture, and context. Double arrows represent interactions among the elements (interdependence relations). Even if initial elements come first, they can influence and be influenced later by intermediate elements and resultant elements of interorganizational culture.

Thus, our study indicates that interorganizational culture can be seen as a culture of intersection, because of the association of the cultural perspectives between suppliers and intermediaries, or, also, a culture of boundaries. This is due to the fact that culture can create boundaries and allow shared meanings among boundaries (Halley, 2001), and relationships involve the meeting point of different cultures (Plewa, 2009). It would be also possible to face interorganizational culture as boundary spanners' culture, involving the interaction of the intermediaries' boundary spanners (including the owners) with the companies' boundary spanners, mainly in those areas in which they predominate, like marketing/sales. Culture builds cohesion between people from different organizations and works as a bonding agent (Grueso-Hinestroza \& Antón-Rubio, 2015). As relationship marketing practices depend on how much they are valued at the organizational level and rooted in organizational culture, in this regard they play a critical role, because they allow the development of meeting points of different cultures, since interaction with people is built in cultural premises (Ellis et al., 2006; Plewa, 2009; Winklhofer et al., 2006).

\section{Concluding remarks}

Relationship marketing consists of processes of interaction and engagement to maintain long-term cooperative relationships (Hakansson \& Snehota, 1995; Morgan \& Hunt, 1994; Palmatier, 2008). Although the field of relationship marketing has been an important topic of academic research for over two decades, it appears even more significant when relationships are considered complex and multifaceted (Payne \& Frow, 2017).

Interorganizational relationships, as well as organizational cultures, are complex. To be developed, they rely on communication, learning, trust, commitment, shared meanings and symbols. Relationships are not chosen, they are developed (Hunt et al., 2006). On the other hand, organizational culture presents variation and contradiction (Alvesson, 2013). 
This study has analyzed the contribution of buyer-seller relationships in the changes on the organizational cultures involved. It was possible to identify that relationships interfere in cultural issues, considering quantity and quality of interaction among different organizations, trust, commitment, cooperation and learning processes. These changes, not restricted to the intermediaries, will interfere in the continuity of the relationships. About that, the role of the boundary spanner as a professional of boundaries was noticed, as well as the need to consider the role conflicts and the employee turnover levels.

Benefits of interorganizational relationships will depend on how much they are valued in the organizational levels and rooted in the organizational cultures (Winklhofer et al. 2006). It has been noticed that relationship marketing is not only related to strategies from the investigated cases, but it is also an element of their cultures.

As theoretical contributions of this study, it was evident the explanation power and the complexity of the multiple cultural perspectives from Martin et al. (2006). On the other hand, it has become clear the importance of the relationship constituent elements in the cultural changes, especially trust (Pitsis et al., 2004). Another significant issue is the need to consider learning, mainly the informal one (JanowiczPanjaitana \& Noorderhavenb, 2008).

Besides, this study has identified the existence, although restricted, of an interorganizational culture. It is a culture originated from relationships, an intersection of cultures, a culture of boundaries. Interorganizational culture can coexist with other cultures, even because it is a product of theirs and their interactions, which could increase the scope of those involved, thus reducing preconceptions. However, attention is drawn to the fact that organizational cultures may, simultaneously, create cohesion and guidance, making the collective action and the organizational life possible because of that, but also restrict autonomy, creativity and questioning
(Alvesson, 2013). This may be associated to the dark side of the interorganizational culture.

Simultaneously, this study contributes to marketing practices by pointing out the need to be attentive to the relations between relationship marketing actions and organizational culture. Relationship happens because there is a cultural basis (Ellis et al., 2006). It also highlights the attention to the role of boundary spanners (Araujo et al., 2003), their role conflicts as well as their turnover levels. In this regard, a proper channel for interaction and communication among organizations can facilitate the development of combined interpretation, which could reduce the differences (Fang, Fang, Chou, Yang, \& Tsai, 2011). Moreover, by performing a qualitative multiple-case study involving organizational culture and relationship marketing, it contributes to marketing discipline by the need to more deepgoing case study research to address the world complexity (Gummesson, 2017).

Regarding the limitations of the study, the lack of more observation moments has been noted. In addition, the study focused on interorganizational relationships in marketing channels from two cases. This paper suggests future studies related to the role of the boundary spanners in cultural changes; the nature and the dynamics of intersection areas among different cultural perspectives, considering the proposed conceptual framework in marketing channels as well as in other interorganizational arrangements, such as cooperative networks and clusters; the investigation of the dark side of interorganizational culture.

\section{References}

Achrol, R. S., Reve, T., \& Stern, L. W. (1983). The environment of marketing channel dyads: A framework for comparative analysis. Journal of Marketing, 47(4), 55-67.

Agariya, A. K., \& Singh, D. (2011). What really defines Relationship Marketing? A review of definitions and general and sector-specific 
defining constructs. Journal of Relationship Marketing, 10(4), 203-237.

Altinay, L., \& Brookes, M. (2012). Factors influencing relationship development in franchise partnerships. Journal of Services Marketing, 26(4), 278-292.

Alvesson, M. (2013). Understanding organizational culture. London, UK: Sage.

Alvesson, M., \& Sveningsson, S. (2008). Changing organizational culture: Cultural change work in progress. Abingdon, UK: Routledge.

Araujo, L., Dubois, A., \& Gadde, L. (2003). The multiple boundaries of the Firm. Journal of Management Studies, 4O(5), 1255-1277.

Ballantyne, D., Christopher, M., \& Payne, A. (2003). Relationship marketing: Looking back, looking forward. Marketing Theory, 3(1), 159166.

Batt, P. J., \& Purchase, S. (2004). Managing collaboration within networks and relationships. Industrial Marketing Management, 33(3), 169174.

Beugelsdijk, S., Koen, C., \& Noorderhaven, N. (2009). A dyadic approach to the impact of differences in organizational culture on relationship performance. Industrial Marketing Management, 38(3), 312-323.

Cannon, J. P., \& Perreault, W. D., Jr. (1999). Buyer-seller relationships in business markets. Journal of Marketing Research, 36(4), 436-460.

Cavedon, N. R. (2003). Antropologia para administradores, Porto Alegre, BR: UFRGS.

Charmaz, K. (2014). Constructing grounded theory. London, UK: Sage.

Dauber, D., Fink, G., \& Yolles, M. (2012). A configuration model of organizational culture. Sage Open, 2(1), 1-16.
Deshpandé, R., \& Webster, F. E., Jr. (1989). Organizational culture and marketing: defining the research agenda. Journal of Marketing, 53(1), 3-15.

Ellis, N., Lowe, S., \& Purchase, S. (2006). Towards a re-interpretation of industrial networks: A discursive view of culture. The IMP Journal, 1(2), 20-40.

Fang, S. R., Fang, S. C., Chou, C. H., Yang, S. M., \& Tsai, F. S. (2011). Relationship learning and innovation: The role of relationship-specific memory. Industrial Marketing Management, 4O(5), 743-753.

Friedman, R. A., \& Podolny, J. (1992). Differentiation of boundary spanning roles. Administrative Science Quarterly, 37, 28-47.

Gagliardi, P. (1986). The creation and change of organizational cultures: A conceptual framework. Organization Studies, 7(2), 117-134.

Gebhardt, G. F., Carpenter, G. S., \& Sherry, J. F., Jr. (2006). Creating a market orientation: A longitudinal, multifirm, grounded analysis of cultural transformation. Journal of Marketing, $70(4), 37-55$.

Geyskens, I., Steenkamp, J., \& Kumar, N. (1999). A meta-analysis of satisfaction in marketing channel relationships. Journal of Marketing Research, 36(2), 223-238.

Gregory, B. T., Harris, S. G., Armenakis, A. A. \& Shook, C. L. (2009). Organizational culture and effectiveness: A study of values, attitudes, and organizational outcomes. Journal of Business Research, 62(7), 673-679.

Grueso-Hinestroza, M. P., \& Antón-Rubio, M. C. (2015). Cultural values in interorganizational networks: A proposal from the model of Shalom Shwartz (1992). Investigación y Desarrollo, 23(2), 369-390. 
Gubba, E. G., \& Lincoln, Y. S. (2011). Paradigmatic controversies, contradictions, and emerging confluences, revisited. In N. K. Denzin, \& Y. S. Lincoln (Eds), The SAGE Handbook of Qualitative Research, (3rd. ed., Cap. 8, pp. 191234). Thousand Oaks, CA: Sage.

Gummesson, E. (2008). Total relationship marketing (3rd ed.). Oxford, UK: Elsevier: Butterworth-Heinemann.

Gummesson, E. (2017). From relationship marketing to total relationship marketing and beyond. Journal of Services Marketing, 31(1), 16-19.

Hakansson, H., \& Snehota, I. (1995). Developing relationships in business networks. London, UK: Routledge.

Halley, A. A. (2001). Applications of boundary theory to organizational and interorganizational culture. In R. J. Stupak, \& P. M. Leitner (Eds.), Handbook of Public Quality Management (pp. 135-147). New York, NY: Marcel Dekker.

Haytko, D. L. (2004). Firm-to-firm and interpersonal relationships. Journal of the Academy of Marketing Science, 32(3), 312-328.

Hofstede, G. (2001). Culture's consequences: Comparing values, behaviors, institutions and organizations across nations. Thousand Oaks, CA: Sage.

Hogan, S. J., \& Coote, L. V. (2014). Organizational culture, innovation, and performance: A test of Schein's model. Journal of Business Research, 67(8), 1609-1621.

Hunt, S. D., Arnett, D. B., \& Madhavaram, S. (2006). The explanatory foundations of relationship marketing theory. Journal of Business Industrial Marketing, 21(2), 72-87.

Iglesias, O., Sauquet, A., \& Montaña, J. (2011). The role of corporate culture in relationship marketing. European Journal of Marketing, 45(4), 631- 650 .
Janowicz-Panjaitana, M., \& Noorderhavenb, N. G. (2008). Formal and informal interorganizational learning within strategic alliances. Research Policy, 3(8), 1337-1355.

Kang, B., \& Jindal, R. P. (2015). Opportunism in buyer-seller relationships: Some unexplored antecedents. Journal of Business Research, 68(3), 735-742.

Lee, S. J., Kim, J., \& Park, B. I. (2015). Culture clashes in cross-border mergers and acquisitions: A case study of Sweden's Volvo and South Korea's Samsung. International Business Review, 24(4), 580-593.

Lu, V. N., Plewa, C., \& Ho, J. (2016). Managing governmental business relationships: The impact of organisational culture difference and compatibility. Australasian Marketing Journal (AMJ), 24(1), 93-100.

Lucas, C., \& Kline, T. (2008). Understanding the influence of organizational culture and group dynamics on organizational change and learning. Learning Organization, 15(3), 277-287.

Luthans, F. (2010). Organizational behavior (12nd ed.). New York, NY: McGraw-Hill.

Martin, J., Frost, P. J., \& O’Neil, O. A. (2006). Organizational culture: Beyond struggles for intellectual dominance. In S. R. Clegg, C. Hardy, T. B. Lawrence, \& W. R. Nord (Eds.). Handbook of organizational studies (2nd. ed., pp. 599-621). London, UK: Sage.

Merriam, S. B. (2009). Qualitative research. San Francisco, CA: Jossey-Bass.

Miles, M. B., Huberman, A. M., \& Saldaña, J. (2014). Qualitative data analysis (3rd ed.). Thousand Oaks, CA: Sage.

Miquel-Romero, M. J., Caplliure-Giner, E. M., \& Adame-Sánchez, C. (2014). Relationship marketing management: Its importance in private 
label extension. Journal of Business Research, 67(5), 667-672.

Mohr, D., Young, G. J., \& Burgess, J. F. (2012). Employee turnover and operational performance: The moderating effect of grouporiented organizational culture. Human Resource Management Journal, 22(2), 216-233.

Moorman, C., \& Day, G. S. (2016). Organizing for marketing excellence. Journal of Marketing, 80(6), 6-35.

Morgan, R. M. (2000). Relationship marketing and marketing strategy: The evolution of relationship marketing strategy within the organization. In J. Sheth, \& A. Parvatiyar (Eds.), Handbook of relationship marketing (Cap. 18, pp. 481-504). Thousand Oaks, CA: Sage.

Morgan, R. M., \& Hunt, S. D. (1994). The commitment-trust theory of relationship marketing. Journal of Marketing, 58(3), 20-38.

Narasimhan, L., Srinivasan, K., \& Sudhir, K. (2015). Editorial - marketing science in emerging markets. Marketing Science, 34(4), 473-479.

Ogbonna, E., \& Harris, L. C. (2014). Organizational cultural perpetuation: A case study of an english premier league football club. British Journal of Management, 25(4), 667-686.

Palmatier, R. W. (2008). Relationship marketing. Cambridge, MA: Marketing Science Institute.

Palmatier, R. W., Dant, R., Grewal, D., \& Evans, K. (2006). Factors influencing the effectiveness of relationship marketing: A meta-analysis. Journal of Marketing, 7O(4), 136-153.

Payne, A., \& Frow, P. (2017). Relationship marketing: Looking backwards towards the future. Journal of Services Marketing, 31(1), 11-15.

Pels, J., Moller, K., \& Saren, M. (2009). Do we really understand business marketing? Getting beyond the RM - BM matrimony. Journal of Business \& Industrial Marketing, 24(5), 322-336.
Pitsis, T. S., Kornberger, M., \& Clegg, S. (2004). The art of managing relationships in interorganizational collaboration.M@nagement, 7(3), 47-67.

Plewa, C. (2009). Exploring organizational culture difference in relationship dyads. Australasian Marketing Journal, 17(1), 46-57.

Saenz, M. J., Revilla, E., \& Knoppen, D. (2014). Absorptive capacity in buyer-supplier relationships: Empirical evidence of its mediating role. Journal of Supply Chain Management, 50(2), $18-40$

Schakett, T., Flaschner, A., Gao, T., \& El-Ansary, A. (2011). Effects of social bonding in businessto-business relationships. Journal of Relationship Marketing, 10(4), 264-280.

Scheer, L. K., Miao, C. F., \& Palmatier, R. W. (2015). Dependence and interdependence in marketing relationships: Meta-analytic insights. Journal of the Academy of Marketing Science, 43(6), 694-712

Schein, E. H. (1991). What is culture? In P. J. Frost, L. F. Moore, M. R. Louis, C. C. Lundberg, \& J. Martin (Eds.). Reframing organizational culture (pp. 243-253). Newbury Park, CA: Sage.

Singh, J., \& Rhoads, G. K. (1991). Boundary role ambiguity in marketing oriented positions: A multidimensional, multifaceted operationalization. Journal of Marketing Research, 28(3), 328-338.

Strati, A. (1998). Organizational symbolism as a social construction: A perspective from the sociology of knowledge. Human Relations, 51(11), 1379-1402.

Van Maanen, J., \& Barley, S. (1985). Cultural organization: Fragments of a theory. In P. J. Frost, L. F. Moore, M. R. Louis, C. C. Lundberg, \& J. Martin (Eds.) Organizational Culture, (pp. 3153). Newbury Park: CA Sage. 
Vetráková, M., \& Smerek, L. (2016). Diagnosing organizational culture in national and intercultural context. E+ M Ekonomie a Management, 19(1), 62.

Wang, J. J., \& Zhang, C. (2017). The impact of value congruence on marketing channel relationship. Industrial Marketing Management, 62, 118-127.

Winklhofer, H., Pressey, A., \& Tzokas, N. (2006). A cultural perspective of relationship orientation: Using organizational culture to support a supply relationship orientation. Journal of Marketing Management, 22(1), 169-194.

Yin, R. K. (2014). Case study research (5th ed.). Thousand Oaks, CA: Sage.
Yin, S., Lu, F., Yang, Y., \& Jing, R. (2014). Organizational culture evolution: An imprinting perspective. Journal of Organizational Change Management, 27(6), 973-994.

\section{Notes}

1 Article derived from the doctoral thesis: "Marketing de relacionamento e cultura organizacional : uma perspectiva interorganizacional" defended by Fabiano Larentis in 2010, at the Universidade Federal do Rio Grande do Sul. Escola de Administraçáo. Programa de Pós-Graduação em Administração, under the orientation of Prof. Dr. Luiz Antônio Slongo.

2 A preliminary version of this article was presented on XXXIV EnANPAD 2010, Rio de Janeiro. "Marketing de Relacionamento e Transformaçôes Culturais Organizacionais: Um Estudo de Casos Múltiplos em Díades"

\section{About the authors:}

1. Fabiano Larentis, Doctor in Management, Federal University of Rio Grande do Sul, Porto Alegre, Brazil. E-mail: flarenti@ucs.br

ORCID

(D) 0000-0001-8390-0271

2. Claudia Simone Antonello, Doctor in Management, Federal University of Rio Grande do Sul, Porto Alegre, Brazil. E-mail: claudia.antonello@ufrgs.br

ORCIID

(D) 0000-0001-9654-5125

3. Luiz Antonio Slongo, Doctor in Management, University of São Paulo, São Paulo, Brazil. E-mail: luiz. slongo@ufrgs.br

ORCIID

(D) 0000-0002-8269-4338

\section{Contribution of each author:}

\begin{tabular}{|c|c|c|c|}
\hline Contribution & $\begin{array}{l}\text { Fabiano } \\
\text { Larentis }\end{array}$ & $\begin{array}{l}\text { Claudia Simone } \\
\text { Antonello }\end{array}$ & $\begin{array}{l}\text { Luiz Antonio } \\
\text { Slongo }\end{array}$ \\
\hline 1. Definition of research problem & $\sqrt{ }$ & $\sqrt{ }$ & $\sqrt{ }$ \\
\hline 2. Development of hypotheses or research questions (empirical studies) & $\sqrt{ }$ & $\sqrt{ }$ & $\sqrt{ }$ \\
\hline 3. Development of theoretical propositions (theoretical work) & $\sqrt{ }$ & & $\sqrt{ }$ \\
\hline 4. Theoretical foundation / Literature review & $\sqrt{ }$ & $\sqrt{ }$ & $\sqrt{ }$ \\
\hline 5. Definition of methodological procedures & $\sqrt{ }$ & $\sqrt{ }$ & \\
\hline 6. Data collection & $\sqrt{ }$ & & \\
\hline 7. Statistical analysis & - & - & - \\
\hline 8. Analysis and interpretation of data & $\sqrt{ }$ & $\sqrt{ }$ & \\
\hline 9. Critical review of the manuscript & & $\sqrt{ }$ & $\sqrt{ }$ \\
\hline 10. Manuscript writing & $\sqrt{ }$ & $\sqrt{ }$ & \\
\hline 11. Other - Development of the framework from the analysis & $\sqrt{ }$ & $\sqrt{ }$ & \\
\hline
\end{tabular}

